\title{
CORRECTION OF SOIL ACIDITY IN THE SUBSURFACE OF AN OXISOL WITH SANDY LOAM TEXTURE UNDER NO-TILLAGE(1)
}

\author{
Otavio Bagiotto Rossato ${ }^{(2)}$, Carlos Alberto Ceretta ${ }^{(3)}$, Leandro Souza \\ da Silva ${ }^{(3)}$, Gustavo Brunetto ${ }^{(4)}$, Jaqueline Cristiane Adorna ${ }^{(5)}$, \\ Eduardo Girotto $^{(6)}$ \& Cledimar Rogério Lorenzi ${ }^{(7)}$
}

\begin{abstract}
In Rio Grande do Sul State (RS), Southern Brazil, aluminum saturation in many areas under no-till system is high and base saturation low in the $0.10-0.20 \mathrm{~m}$ layer (subsurface), which may reduce the grain yield of annual crops. The objective of this study was to evaluate if the occurrence of high aluminum saturation and low base saturation in the subsurface, under a no-till system, represents a restrictive environment for crop production, as well as to evaluate forms of lime incorporation for soil acidity correction in the subsurface. For this purpose, an experiment was carried out with soybean (2005/2006), corn (2006/2007), wheat (2007) and soybean (2007/2008) crops, in a Rhodic Hapludox (USDA, 1999) with sandy loam texture, under no-till for four years in the county of Tupanciretã (RS). The six treatments were: no-tillage with and without lime, plowing with and without lime, and chiseling with and without lime. The values of $\mathrm{pH}-\mathrm{H}_{2} \mathrm{O}$, aluminum saturation and base saturation were evaluated 24 months after treatment application in the layers $0-0.05 ; 0.05-0.10 ; 0.10-0.15 ; 0.15-0.20$ and $0.20-0.30 \mathrm{~m}$. The yields of soybean $(2005 /$ 2006), corn (2006/2007), wheat (2007) and soybean (2007/2008) were evaluated. Soil acidity in the subsurface did not affect crop yield when the acidity in the layer from 0-0.10 $\mathrm{m}$ was at levels for which lime application is not recommended, according to CQFSRS/SC (2004). Lime incorporation through plowing was the most efficient way of correcting acidity at deeper levels.
\end{abstract}

Index terms: lime, soil tillage systems, aluminum saturation, base saturation.

\footnotetext{
(1) Parte da Dissertação de Mestrado do primeiro autor, apresentada no Programa de Pós-Graduação em Ciência do Solo da Universidade Federal de Santa Maria - UFSM. Recebido para publicação em setembro de 2008 e aprovado em março de 2009.

${ }^{(2)}$ Doutorando em Agronomia - Energia na Agricultura da Faculdade de Ciências Agronômicas, Universidade Estadual Paulista - FCA/UNESP. Rua Humberto Milonesi Junior 1100, Altos do Paraiso, CEP 18610-070 Botucatu (SP). Bolsista da Capes. Email: bagiottorossato@yahoo.com.br

${ }^{(3)}$ Professor do Departamento de Solos da Universidade Federal de Santa Maria - UFSM. Caixa Postal 221, CEP 97105-900 Santa Maria (RS). Bolsista do CNPq. E-mails: carlosceretta@gmail.com; leandro@smail.ufsm.br

(4) Pós-Doutorando do Programa de Pós-Graduação em Ciência do Solo, UfSM. Bolsista da Capes. E-mail: brunetto.gustavo@gmail.com

(5) Mestranda em Agronomia - Agricultura da Faculdade de Ciências Agronômicas, FCA/UNESP. Bolsista FAPESP. E-mail: adornajc@yahoo.com.br

(6) Doutorando do Programa de Pós-Graduação em Ciência do Solo , UFSM. E-mail: eduardogirotto@hotmail.com

(7) Acadêmico do Curso de Agronomia, UFSM. E-mail: crlourenzi@mail.ufsm.br
} 


\title{
RESUMO: CORREÇÃO DA ACIDEZ DO SOLO EM SUBSUPERFÍCIE DE UM LATOSSOLO DE TEXTURA FRANCO-ARENOSA SOB PLANTIO DIRETO
}

\begin{abstract}
No Rio Grande do Sul (RS), muitas áreas sob plantio direto apresentam elevada saturação por Al e baixa saturação por bases na camada de 0,10-0,20 m (subsuperfície), e isso pode diminuir a produção de grãos de culturas anuais. O objetivo do presente trabalho foi avaliar se a ocorrência de alta saturação por Al e baixa saturação por bases em subsuperfície $(0,10-0,20 \mathrm{~m})$, no plantio direto, pode representar um ambiente restritivo para a produção de culturas, bem como avaliar os modos de incorporação de calcário na correção da acidez do solo em subsuperfície. Para isso, foi realizado um experimento com os cultivos de soja (2005/ 2006), milho (2006/2007), trigo (2007) e soja (2007/2008), em um Latossolo Vermelho distrófico típico (Embrapa, 2006) de textura franco arenosa, há quatro anos sob plantio direto, no município de Tupanciretã (RS). Os seis tratamentos foram: sem revolvimento com ou sem calcário; lavração com ou sem calcário; e escarificação com ou sem calcário. Aos 24 meses após a aplicação dos tratamentos e nas camadas de 0-0,05, 0,05-0,10, 0,10-0,15, 0,15-0,20 e 0,20-0,30 m, foram avaliados os valores de $\mathrm{pH}-\mathrm{H}_{2} \mathrm{O}$, saturação por Al e por bases. Avaliou-se a produtividade de soja (2005/2006), milho (2006/2007), trigo (2007) e soja (2007/2008). A acidez do solo em subsuperfície não alterou a produtividade das culturas quando as propriedades de acidez na camada de 0-0,10 m estavam em níveis em que não se recomenda a aplicação de calcário, segundo a CQFSRS/SC (2004). A incorporação de calcário com aração foi o modo mais eficiente de corrigir a acidez em profundidade.
\end{abstract}

\section{Termos de indexação: calcário, sistemas de preparo do solo, saturação por alumínio, saturação} por bases.

\section{INTRODUCTION}

In the southern region of Brazil, no-till systems expanded mainly in the 90 s, to such an extent that in the agricultural harvest of 2005/2006, around 25.5 million hectares of annual crops in Brazil were cultivated under this system (FEBRAPDP, 2007). Nevertheless, it is believed that only in parts of this area the recommendations for the system in terms of the correction of soil acidity and nutrient contents in the layer $0-0.20 \mathrm{~m}$ were observed.

Based on existing and accumulated knowledge, especially in the 90s, the Chemical and Soil Fertility Commission of the Southern Regional Nucleus of the Brazilian Soil Science Society (CQFSRS/SC, 2004) published a new edition of the Fertilization and Liming Manual for the States of Rio Grande do Sul (RS) and Santa Catarina (SC). For liming in a consolidated no-till system the manual recommends surface lime application when the water $\mathrm{pH}$ is less than 5.5 and base saturation less than $65 \%$ in the $0-0.10$ m layer. Nevertheless, Martinazzo (2006) reports that Al saturation in no-till crops on the Plateau of Rio Grande do Sul, an important grain-producing region, is generally high and base saturation low, below the layer of $0.10 \mathrm{~m}$, i.e., a reduction in grain yield may be expected. In these cases, lime surface application might not be effective for soil correction at deeper levels and may result in reduced grain yields, which is the hypothesis of this study.
In a conventional tillage system, plowing and disking were the most common forms of lime incorporation; however, with the implementation of the no-till system, liming came to be performed at the soil surface. Some studies in the beginning of the 90s show that surface liming in no-till areas has altered the chemical attributes in the soil profile, improving the environment for root growth (Cassol, 1995; Pöttker \& Ben, 1998; Rheinheimer et al., 2000; Amaral \& Anghinoni, 2001; Moreira et al., 2001; Caires et al., 2006). Nevertheless, it has been observed that in most situations, the effect of liming is limited to the 0 $0.10 \mathrm{~m}$ soil layer, and is in some cases physically restricted by soil compaction or pore sealing (Kaminski et al., 2005).

From the observation that surface liming corrects soil acidity only in the top centimeters of the soil profile, some studies were developed to evaluate the form of lime incorporation in no-till areas. According to Wheirich Neto et al. (2000), the effect of lime, when incorporated by one plowing and double disking, and with chiseling and passing twice with a disk harrow, is restricted to a depth of $0.10 \mathrm{~m}$, three months after liming. Conversely, Sá (1999), after four years of lime incorporation, observed that the use of a disk plow and moldboard plow improved the soil chemical attributes in terms of soil acidity, down to a depth of approximately $0.30 \mathrm{~m}$. Alternative forms of lime incorporation, such as chiseling, are used for the sake of incorporating lime at lower costs and with less soil 
disaggregation and erosion risks and with greater water infiltration in the soil profile. However, scientific studies related to the forms of lime incorporation and efficiency in soil acidity correction are lacking. According to Sá (1999), lime incorporation through chiseling modified the soil chemical attributes down to a depth of $0.10 \mathrm{~m}$, one year after application. The same author reported that from the second year on, no differences in the soil chemical attributes between lime application at the soil surface and incorporation with chiseling were observed, nor were there differences in grain yields.

This study had the objective of evaluating if the occurrence of high $\mathrm{Al}$ saturation and low base saturation at the subsurface $(0.10-0.20 \mathrm{~m})$, in the no-till system, may represent a restrictive environment for crop yields and of evaluating forms of lime incorporation for soil acidity correction in the subsurface.

\section{MATERIAL AND METHODS}

The study was conducted from June 2005 to May 2008 in no-till crops for four years in the county of Tupanciretã (RS), region of the Planalto Médio (mid altitude plateau) (28 $58^{\prime} 43,3^{\prime \prime}$ S and $53^{\circ} 38^{\prime} 26,4$ "W. Before implantation of the experiment (Table 1) ten soil subsamples were collected from the 0-0.10 and 0.10-0.20 m layers, at the same sampling point, which represented one sample per layer. Near these points, soil subsamples were collected from the $0-0.20 \mathrm{~m}$ layer, to form one sample. The soil was a Rhodic Hapludox (USDA, 1999), with 200, 720 and $80 \mathrm{~g} \mathrm{~kg}^{-1}$ clay, sand and silt respectively in the $0-0.20 \mathrm{~m}$ layer. Other chemical attributes are given in table 1 .

Table 1. Chemical attributes in an Oxisol under the no-till system before implantation of the experiment

\begin{tabular}{|c|c|c|c|}
\hline \multirow{2}{*}{ Attribute $^{(1)}$} & \multicolumn{3}{|c|}{ Soil layers (m) } \\
\hline & $0-0.10$ & $0.10-0.20$ & $0-0.20$ \\
\hline Organic material, $\mathrm{g} \mathrm{kg}^{-1}$ & 19 & 12 & 17 \\
\hline $\mathrm{pH}-\mathrm{H}_{2} \mathrm{O}$ & 5.5 & 5.1 & 5.4 \\
\hline SMP Index & 6.4 & 5.9 & 6.1 \\
\hline Aluminum saturation, $\%$ & 0 & 2.4 & 4.0 \\
\hline Base saturation, $\%$ & 65 & 39 & 57 \\
\hline Effective CEC, $\mathrm{cmol}_{\mathrm{c}} \mathrm{dm}^{-3}$ & 5.4 & 4.1 & 5.3 \\
\hline $\mathrm{CEC} \mathrm{pH} \mathrm{7,} \mathrm{cmol}_{\mathrm{c}} \mathrm{dm}^{-3}$ & 8.4 & 8.0 & 9.0 \\
\hline Exchangeable $\mathrm{Al}, \mathrm{cmol}_{\mathrm{c}} \mathrm{dm}^{-3}$ & 0.0 & 1.0 & 0.2 \\
\hline Exchangeable $\mathrm{Mg}, \mathrm{cmol}_{\mathrm{c}} \mathrm{dm}^{-3}$ & 2.4 & 1.5 & 2.2 \\
\hline Exchangeable $\mathrm{Ca}, \mathrm{cmol}_{\mathrm{c}} \mathrm{dm}^{-3}$ & 2.8 & 1.5 & 2.8 \\
\hline Available $\mathrm{P}, \mathrm{mg} \mathrm{dm}^{-3}$ & 13.5 & 3.0 & 6.8 \\
\hline Available $\mathrm{K}, \mathrm{mg} \mathrm{dm}^{-3}$ & 60 & 36 & 48 \\
\hline
\end{tabular}

(1) Determined according to Tedesco et al. (1995) and/or calculated in compliance with the CQFS-RS/SC (2004).
The treatments were: no tillage with and without lime; plowing with and without lime; chiseling with and without lime. The lime rate was based on the value of water $\mathrm{pH}$ and the SMP (Shoemaker, McLean, Pratt) index, a method described by Shoemaker et al. (1961), representing the lime rate needed to raise the water $\mathrm{pH}$ up to 6.0 in the $0-0.20 \mathrm{~m}$ layer (CQFSRS/ $\mathrm{SC}, 2004)$. The experiment was arranged in a randomized block design with split plots and four replications. The main plots consisted of soil tillage forms (no tillage, plowing and chiseling), and the subplots of presence and absence of lime application. In the $80 \mathrm{~m}^{2}$ plots $(10 \times 8 \mathrm{~m})$, chiseling was performed at a depth of approximately $0.32 \mathrm{~m}$ and plowing at a depth of around $0.20 \mathrm{~m}$. The following crops were planted in succession: black oat (Avena strigosa Schereb Schreb); soybean (Glycine max (L.) Merrill); natural reseeding - oats + ryegrass (Lolium multiflorum L.); corn (Zea mays L.); turnips (Raphanus sativus L.), wheat (Triticum aestivum L.) and soybean.

At wheat tillering, 24 months after the application of the treatments, soil was collected from the layers $0-0.05 ; 0.05-0.10 ; 0.10-0.15 ; 0.15-0.20$ and $0.20-$ $0.30 \mathrm{~m}$. The soil was dried, sieved ( $2 \mathrm{~mm}$ mesh) and prepared for analyses of water $\mathrm{pH}$ (1:1), SMP $\mathrm{pH}$, exchangeable $\mathrm{Ca}, \mathrm{Mg}$ and $\mathrm{Al}$, and available $\mathrm{K}$ and $\mathrm{P}$, according to the method described by Tedesco et al. (1995). In the first year soybean was harvested in an area of $8 \mathrm{~m}^{2}$, corn in $16.96 \mathrm{~m}^{2}$, wheat in $4.08 \mathrm{~m}^{2}$, and soybean in $6.4 \mathrm{~m}^{2}$.

The data of soil chemical attributes and grain yields were submitted to variance analysis and upon significance of the effects indicated by variance analysis, means were compared by the Tukey test $(p<0.05)$. For data of the soil attributes, the forms of tillage were considered as plots, liming as subplots and the layers sampled as subsubplots, with restriction to the sampled layer factor.

\section{RESULTS AND DISCUSSION}

Results show that after 24 months of application of surface lime in the no-till system, there was only a significant increase in the water $\mathrm{pH}$ values in the 0-0.05 m layer (Figure 1a). Lime incorporation through plowing increased the $\mathrm{pH}$ values to a depth of $0.15 \mathrm{~m}$ (Figure 1b), while with chiseling the values increased to a depth of $0.10 \mathrm{~m}$ (Figure 1c). It is worth noting that lime incorporation through chiseling and especially with soil plowing without lime application resulted in a reduction of the water $\mathrm{pH}$ values in the 0-0.05 m layer (Figure 1d). This may be attributed to the inversion of the deeper layers of the soil with lower water $\mathrm{pH}$ values. Additionally, although to a lesser extent, soil mobilization increases the soil surface in contact with plant residues, which are more 
quickly decomposed by microorganisms, causing release of organic acids and reduction of the water $\mathrm{pH}$ values, as reported by Sidiras \& Pavan (1985).

Aluminum saturation is an important aspect to be taken into account for liming, so much so that the Chemical and Soil Fertility Commission of the Southern Regional Nucleus of the Brazilian Soil Science Society (CQFSRS/SC, 2004) recommends that when only one of the criteria for decision making is met ( $\mathrm{pH} \leq 5.5$ or $\mathrm{V} \% \leq 65 \%)$, Al saturation should be taken into consideration in the decision whether to apply lime or not. In this case, when $\mathrm{Al}$ saturation is less than $10 \%$, lime application is not recommended. The data obtained therefore show that lime incorporation with plowing only resulted in $\mathrm{Al}$ saturation of less than $10 \%$ down to the level of 0.10-0.15 m (Figure 2b). In contrast, the application of surface lime (Figure 2a) with chiseling (Figure 2c) resulted in $\mathrm{Al}$ saturation of less than $10 \%$ down to the layer of $0.05-0.10 \mathrm{~m}$ only. Once again, chiseling was shown to be an intermediate form between surface application and plowing incorporation with a view to the reduction of $\mathrm{Al}$ saturation at greater soil depths (Figure 2e). This was probably the case because, in addition to lime incorporation through chiseling, soil density is reduced and water infiltration in the profile increased (Camara \& Klein, 2005), which favors conditions for the descent of fine lime particles and dissolution products to greater depths. The effects of subsurface liming can therefore be faster than lime surface application and under conditions of soil compaction.

The reference values of base saturation established for the decision not to apply lime by the CQFS-RS/SC
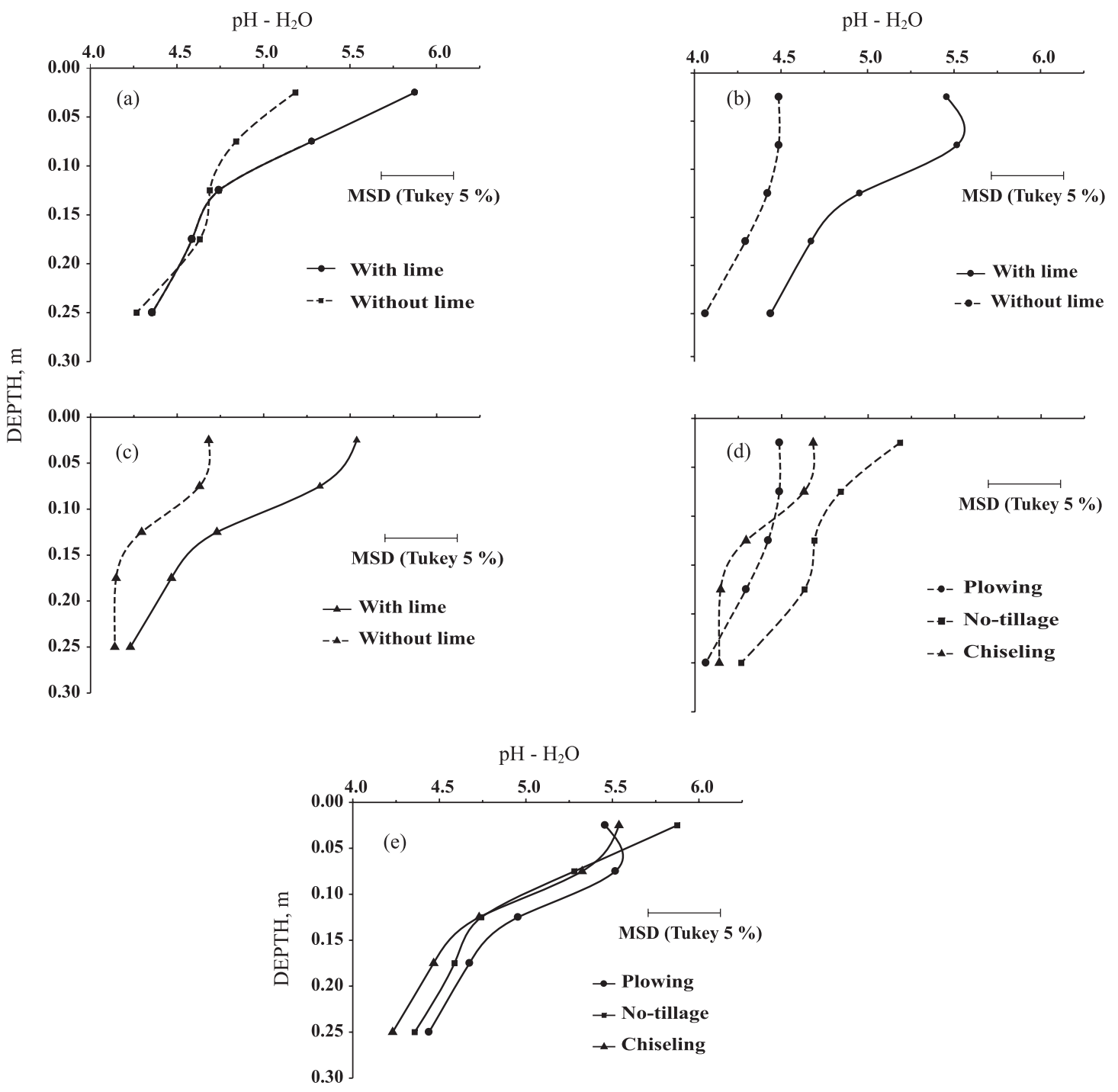

Figure 1. Water pH values in an Oxisol under the no-till system, submitted to the modes of tillage: no tillage (a), plowing (b), chiseling (c) and liming: without lime (d) and with lime (e). MSD (minimum significant difference). 


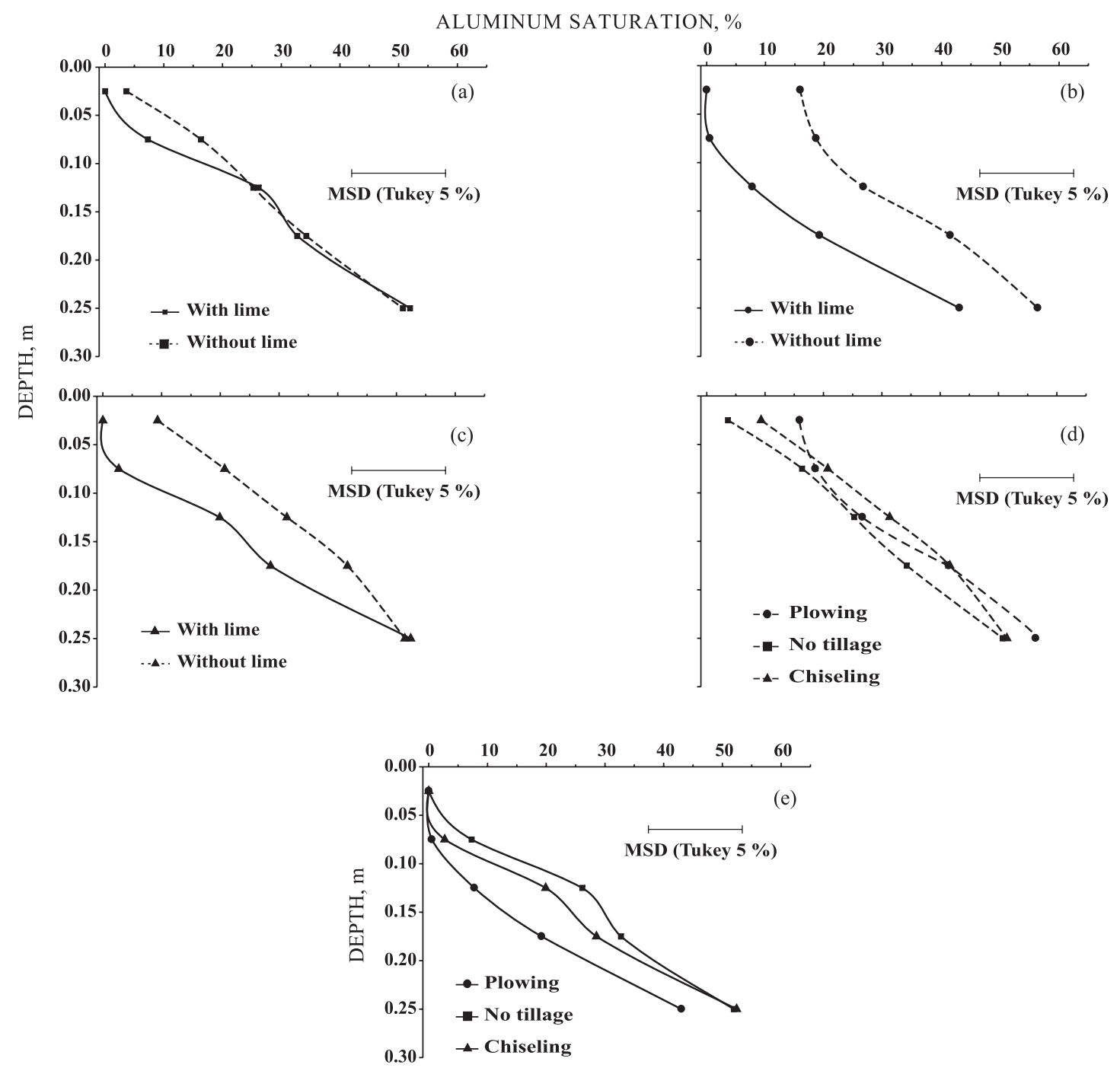

Figure 2. Values of aluminum saturation in an Oxisol under the no-till system, submitted to the modes of tillage: no tillage (a), plowing (b), chiseling (c) and liming: without lime (d) and with lime (e). MSD (minimum significant difference).

(2004) are above $65 \%$ for the no-till system, in the $0-0.10 \mathrm{~m}$ layer. Similar values are observed in the 0.05-0.10 m layer, when lime is incorporated through plowing and chiseling (Figure 3b,c). In contrast, by surface lime application, base saturation values near $65 \%$ were only found in the 0-0.05 m layer, similarly to other studies (Cassol, 1995; Pöttker \& Ben, 1998; Rheinheimer et al., 2000; Moreira et al., 2001; Amaral \& Anghinoni, 2001; Caires et al., 2006; Holzschuh, 2007). The alteration of soil chemical attributes in the most superficial soil layer only when lime is surface applied in the no-till system may be attributed to the low lime solubility and the elevation of the water $\mathrm{pH}$ values in the first centimeters of the soil surface, which reduces lime solubility, as reported by Kaminski et al. (2007).

Plowing was the form of incorporation that caused greatest alterations in the soil chemical attributes in relation to soil acidity, in agreement with the data obtained by Sá (1999), four years after lime incorporation. He observed that the use of the disk plow and moldboard plow caused modifications in the soil chemical attributes to a depth of nearly $0.30 \mathrm{~m}$. In addition, Weirich Neto et al. (2000) observed that plowing and double disking significantly increased base saturation to a depth of $0.15 \mathrm{~m}$.

The forms of lime incorporation did not affect the yields of soybean (2005/2006), corn, wheat and soybean (2007/2008) (Table 2). This lack of crop response to liming agrees with the data obtained by Rheinheimer et al. (2000). However, it is appropriate to emphasize that even by lime incorporation through plowing, it was not possible to reach an $\mathrm{Al}$ saturation below $10 \%$ in the $0.15-0.20 \mathrm{~m}$ layer, nor base saturation close to the desired value in the $0.10-0.15 \mathrm{~m}$ layer (65\%), as established by the CQFSRS/SC (2004). Moreover, it 


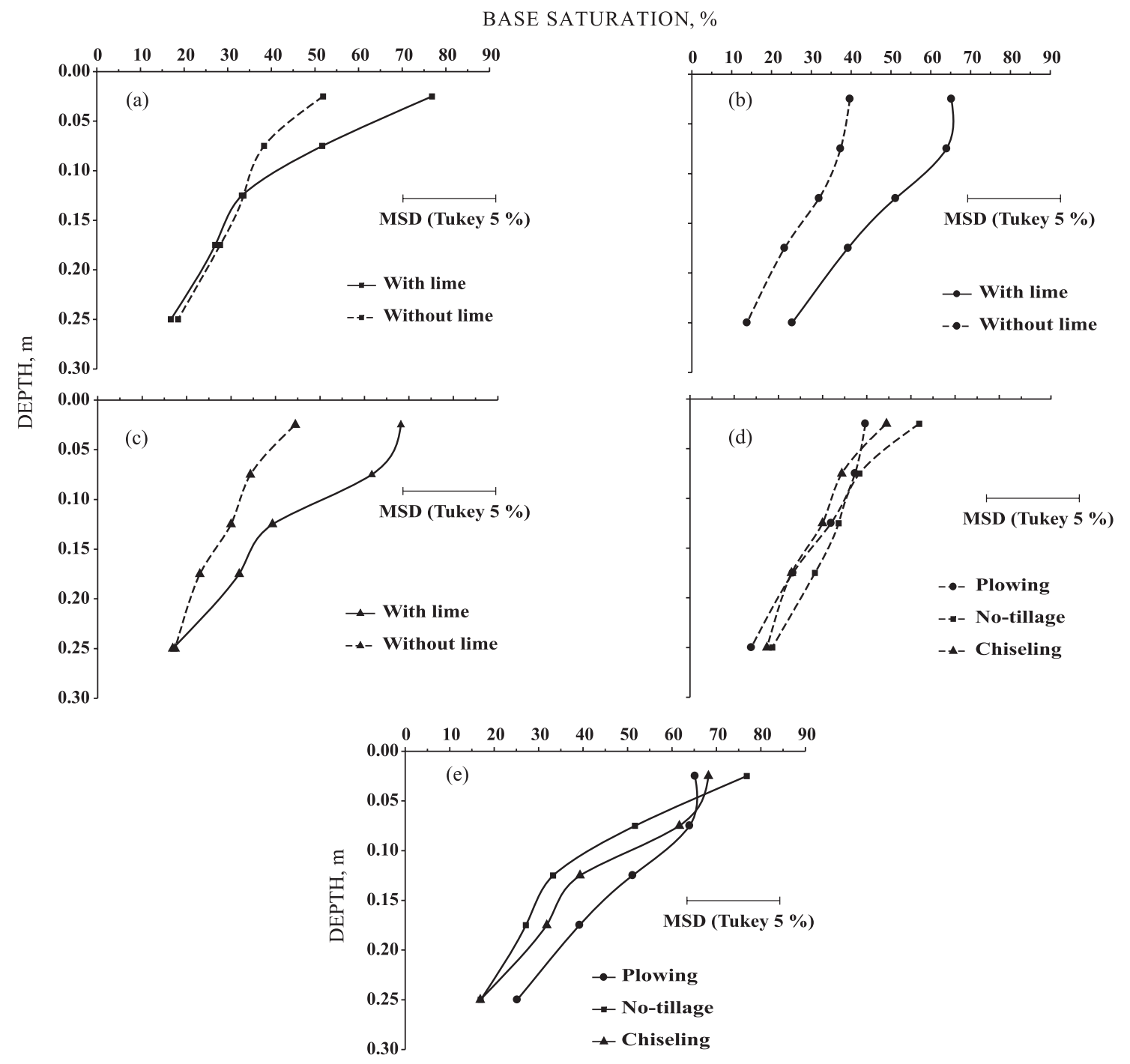

Figure 3. Values of base saturation in an Oxisol under the no-till system, submitted to the modes of tillage: no tillage (a), plowing (b), chiseling (c) and liming: without lime (d) and with lime (e). MSD (minimum significant difference).

must be mentioned that during the crop cycle of soybean there was repeated water stress, mainly in February 2006, and this affected yield, which was $2190 \mathrm{~kg} \mathrm{ha}{ }^{-1}$, near the mean of the treatments. However, water stress could be a condition that may favor crop response to the form of lime incorporation.

The reduction in the corn yield where the treatment included plowing but no liming may indicate a greater sensitivity of the crop to this condition in which plowing brought the deeper soil layers with lower water $\mathrm{pH}$ values, less base saturation and greater $\mathrm{Al}$ content towards the surface, that is, where the greatest part of the plant root mass is concentrated.

The climatic conditions for corn were less restrictive than those for soybean the year before. For corn, it was observed that lime application could be technically recommended if the producer would mobilize the soil through plowing on his property, which is justified by the tendency shown in figures $1 \mathrm{~d}$, $2 \mathrm{~d}$ and $3 \mathrm{~d}$, of reduction in the $\mathrm{pH}$ values, increase in $\mathrm{Al}$ saturation and reduction of base saturation in the uppermost soil layer when plowing is performed without liming. Actually, only in this case would lime application be economically advantageous as well, as reported by Rossato (2008) in the same study.

Greater wheat yields (2007) were obtained with surface lime application in comparison with the treatment without lime and in which the soil was not mobilized (Table 2). However, there was no effect of incorporation nor of liming. In contrast, for soybean in the $07 / 08$ harvest, the yield was greater in the treatments where lime was applied and incorporated with a chisel, in comparison with the treatment where there was only chiseling. Likewise, there was no effect 
Table 2. Grain yield in the harvests of 2005/2006, 2006/2007, 2007 and 2007/2008 in an Oxisol under the no-till system, submitted to different modes of tillage and liming

\begin{tabular}{|c|c|c|c|c|c|c|c|c|}
\hline \multirow{2}{*}{$\begin{array}{c}\text { Mode of } \\
\text { preparation }\end{array}$} & \multicolumn{2}{|c|}{$\begin{array}{c}\text { Soybeans } \\
\text { (harvest } 05 / 06 \text { ) }\end{array}$} & \multicolumn{2}{|c|}{$\begin{array}{c}\text { Corn } \\
\text { (harvest 06/07) }\end{array}$} & \multicolumn{2}{|c|}{$\begin{array}{c}\text { Wheat } \\
\text { (harvest 2007) }\end{array}$} & \multicolumn{2}{|c|}{$\begin{array}{c}\text { Soybeans } \\
\text { (harvest 07/08) }\end{array}$} \\
\hline & $\begin{array}{l}\text { Without } \\
\text { lime }\end{array}$ & $\begin{array}{l}\text { With } \\
\text { lime }\end{array}$ & $\begin{array}{l}\text { Without } \\
\text { lime }\end{array}$ & $\begin{array}{l}\text { With } \\
\text { lime }\end{array}$ & $\begin{array}{l}\text { Without } \\
\text { lime }\end{array}$ & $\begin{array}{l}\text { With } \\
\text { lime }\end{array}$ & $\begin{array}{l}\text { Without } \\
\text { lime }\end{array}$ & $\begin{array}{l}\text { With } \\
\text { lime }\end{array}$ \\
\hline & \multicolumn{8}{|c|}{$\mathrm{kg} \mathrm{ha}^{-1}$} \\
\hline No-tillage & 2084 & $2162 \mathrm{~ns}$ & $5974 \mathrm{aA}$ & $6041 \mathrm{aA}$ & $1980 \mathrm{aB}$ & $2329 \mathrm{aA}$ & $2531 \mathrm{aA}$ & $2516 \mathrm{aA}$ \\
\hline Plowing & 2028 & 2179 & $5252 \mathrm{bB}$ & $6087 \mathrm{aA}$ & $2156 \mathrm{aA}$ & $2227 \mathrm{aA}$ & $2359 \mathrm{aA}$ & $2588 \mathrm{aA}$ \\
\hline Chiseling & 2255 & 2429 & $5837 \mathrm{aA}$ & $5670 \mathrm{aA}$ & $2108 \mathrm{aA}$ & $2252 \mathrm{aA}$ & $2049 \mathrm{aB}$ & $2630 \mathrm{aA}$ \\
\hline $\mathrm{CV}(\%)^{(1)}$ & $7.7^{(2)}$ & $7.4^{(3)}$ & $2.7^{(2)}$ & $4.4^{(3)}$ & $6.46^{(2)}$ & $9.14^{(3)}$ & $8.75^{(2)}$ & $5.68^{(3)}$ \\
\hline
\end{tabular}

${ }^{(1)}$ Coefficient of variation. ${ }^{(2)}$ Main plot. ${ }^{(3)}$ Subplot. ${ }^{\text {ns }}$ : not significant at $5 \%$ probability of error, represents the interaction among the modes of tillage, and liming the same lower case letters in the column refer to the form of tillage and equal capital letters in the row refer to liming and do not differ from each other by the Tukey test $(p<0.05)$.

of incorporation or non- incorporation of the lime applied. In both cases a beginning response of the crops to liming can be observed. This may be related to the increase in soil acidity in the treatments without liming.

The results of this study may also be considered as positive in relation to the recommendations for liming and fertilization for the States of RS and SC (CQFSRS/SC, 2004), because the interpretation of soil analysis before initiating the field work allowed the non-recommendation of liming. Nevertheless, this same recommendation system suggests that soil analysis in the $0.10-0.20 \mathrm{~m}$ layer may be appropriate in certain situations, due to the reasons underlying the hypothesis of this study. It is noteworthy that the assumption that the $\mathrm{Al}$ saturation and base saturation levels may constitute a restrictive environment for adequate root growth was inferred from knowledge generated and divulged based on the conventional system of soil tillage, i.e., plowing and disking. In contrast, in the no-till system there may be a layer with these characteristics below $0.10 \mathrm{~m}$, but negative effects must not necessarily be expected, since the conditions in the $0-0.10 \mathrm{~m}$ layer are adequate. In a study that contributed to this issue Rheinheimer et al. (1994) observed that when the initial growth of tobacco roots occurs in an environment with low $\mathrm{Al}$ content, the plants may later tolerate higher contents of this element.

Another important aspect to be emphasized, for the treatments without liming and with chiseling or a no-till system, is that the values of $\mathrm{pH}$ (Figure 1a,c) and of base saturation (Figure $3 \mathrm{a}, \mathrm{c}$ ), in the $0-0.10 \mathrm{~m}$ layer (average of the 0-0.05 and 0.05-0.10 m layers) were below the recommended by the CQFSRS/SC (2004) but no reduction in corn yield was observed (Table 2). This suggests that in some cases the acidity properties to be considered for the decision of lime application may be lower than those currently recommended for no-till areas. This data agrees with those of Holzschuh (2007) in the same soil type and crop system as in this study, where base saturations around $42 \%$ in the $0-0.10 \mathrm{~m}$ layer and $30 \%$ in the 0-0.20 $\mathrm{m}$ layer were not limiting for the oat and soybean development. In addition, these results agree with those of Caires et al. (1998) where there was no response of soybean to lime application in an Oxisol under a no-till system, with $\mathrm{pH}$ in $\mathrm{CaCl}_{2}$ of $4.5,32 \%$ base saturation and $18 \% \mathrm{Al}$ saturation in the 0 $0.20 \mathrm{~m}$ layer. Likewise, based on a series of experimental results with soybean and corn, Sá (1999) shows improvements in the soil chemical attributes by lime incorporation with plowing and disking, but that this was not reflected in higher crop yields when compared with the surface application of lime. Further details regarding the lack of crop response to liming in the no-till system were also discussed by Pöttker \& Ben (1998), Caires et al. (1999), Caires et al. (2000), Rheinheimer et al. (2000), who attributed this fact to sufficient levels of $\mathrm{Ca}, \mathrm{Mg}, \mathrm{P}$ and $\mathrm{K}$ for plant growth, derived from residual material from previous lime and fertilizer applications. Another factor that helps to understand the results is the lower toxic effect of $\mathrm{Al}$ due to the reduced concentration of toxic elements $\left(\mathrm{Al}^{3+}\right.$ and $\left.\mathrm{AlOH}^{2+}\right)$ and $\mathrm{Al}$ complexation by organic ligands favored by the conditions created in the no-till system, mainly in the surface layer (Salet, 1999). In addition, in the no-till system, roots grow preferentially in biopores, in which the environment is more favorable, in other words, the values of the soil acidity attributes when analyzed as a whole might not represent the real environment of root growth (Gassen \& Kochhann, 1998).

\section{CONCLUSIONS}

1. No yield reduction was observed in the situation where the $\mathrm{pH}$ in water and base saturation are low 
and $\mathrm{Al}$ saturation is high in the $0.10-0.20 \mathrm{~m}$ layer, but yields were reduced when in the $0-0.10 \mathrm{~m}$ layer, the $\mathrm{pH}$ was $\geq 5.5$ and the base saturation $\geq 65 \%$, as indicated by the CQFS-RS/SC (2004).

2. Lime incorporation through plowing was the most efficient form of correcting deep soil acidity.

\section{ACKNOWLEDGEMENTS}

The authors wish to thank Mr. Saulo Facco and his family for granting permission to use the experimental area. They are indebted to the students Renan Vieira, Éder Trentin, Felipe Lorensini and Tadeu Tiecher, supported by undergraduate students' research programs of the Soil Department of the Federal University of Santa Maria (UFSM), and to the employee Luiz Finamor, for his help with activities of the field experiment and laboratory analyses.

\section{LITERATURE CITED}

AMARAL, A.S. \& ANGHINONI, I. Alterações de parâmetros químicos do solo pela reaplicação superficial de calcário no sistema plantio direto. Pesq. Agropec. Bras., 36:695 702,2001

CAIRES, P.E.; CHVEIRI, A.W. \& MADRUGA, E.F. Alterações de características químicas do solo e resposta da soja ao calcário e gesso aplicados na superfície em sistemas de cultivos sem preparo do solo. R. Bras. Ci. Solo, 22:27-34, 1998.

CAIRES, E.F.; FONSECA, A.F.; MENDES, J.; CHUEIRI, W.A. \& MADRUGA, E.F. Produção de milho, trigo e soja em função das alterações das características químicas do solo pela aplicação de calcário e gesso aplicados na superfície em sistema de plantio direto. R. Bras. Ci. Solo, 23:315327,1999

CAIRES, E.F.; BANZATO, D.A. \& FONSECA, A.F. Calagem na superfície em plantio direto. R. Bras. Ci. Solo, 24:161169, 2000.

CAIRES, E.F.; GARBUIO, F.J.; ALLEONI, L.R.F. \& CAMBRI, M.A. Calagem superficial e cobertura de aveia preta antecedendo os cultivos de milho e soja em sistema plantio direto. R. Bras. Ci. Solo, 30:87-98, 2006.

CAMARA, R.K. \& KLEIN, V.A. Escarificação em plantio direto como técnica de conservação do solo e da água. R. Bras. Ci. Solo, 29:78-96, 2005

CASSOL, L.C. Características físicas e químicas do solo e rendimento de culturas após a reaplicação de calcário, com e sem incorporação, em sistemas de preparo. Porto Alegre, Universidade Federal do Rio Grande do Sul, 1995. 98p. (Tese de Mestrado).

COMISSÃO DE QUÍMICA E FERTILIDADE DO SOLO CQFSRS/SC. Manual de adubação e calagem para os estados do Rio Grande do Sul e Santa Catarina. 10.ed. Porto Alegre, SBCS/Núcleo Regional Sul, 2004. 394p.
EMPRESA BRASILEIRA DE PESQUISA AGROPECUÁRIA EMBRAPA. Centro Nacional de Pesquisa de Solos. Sistema brasileiro de classificação de solos. 2.ed. Rio de Janeiro, Embrapa, 2006. 374p.

FEDERAČ̃̃O BRASILEIRA DE PLANTIO DIRETO NA PALHA - FEBRAPDP. Área sob plantio direto. disponível em <http://www.febrapdp.org.br/arquivos.pdf $>$. Accessado em: 23 de Mar., 2007.

GASSEN, D.N. \& KOCHHANN, R.A. Benefícios de insetos de solo sob plantio direto. In: NUERNBERG, N.J., ed. Conceitos e fundamentos do sistema plantio direto. Lages, SBCS/Núcleo Regional Sul, 1998. p.151-160.

HOLZSCHUH, M.J. Eficiência de calcário calcítico e dolomítico na correção da acidez de solos sob plantio direto. Santa Maria, Universidade Federal de Santa Maria, 2007. 85p. (Tese de Mestrado).

KAMINSKI, J.; RHEINHEIMER, D.S.; GATIBONI, L.C.; BRUNETTO, G. \& SAGGIN, A. Eficiência da calagem superficial e incorporada precedendo o sistema plantio direto em um Argissolo sob pastagem natural. R. Bras. Ci. Solo, 69:573-580, 2005.

KAMINSKI, J.; SILVA, L.S.; CERETTA, C.A. \& RHEINHEIMER, D.S. Acidez e calagem no sul do Brasil: Aspectos históricos e perspectivas futuras. In: CERETTA, C.A.; SILVA, L.S. \& REICHERT, J.M., eds. Tópicos em ciência do solo. Viçosa, Sociedade Brasileira de Ciência do Solo, 2007. v.5. p.307-332.

MARTINAZZO, R. Diagnóstico da fertilidade de solos em áreas sob sistema plantio direto consolidado. Santa Maria, Universidade Federal de Santa Maria, 2006. 80p. (Tese de Mestrado).

MOREIRA, S.G.; KIEHL, J.C.; PROCHNOW, L.I. \& PAULETTI, V. Calagem em sistema de semeadura direta e efeitos sobre a acidez do solo, disponibilidade de nutrientes e produtividade de milho e soja. R. Bras. Ci. Solo, 25:71-81, 2001.

PÖTTKER, D. \& BEN, J.R. Calagem para uma rotação de culturas no sistema plantio direto. R. Bras. Ci. Solo, 22:675684,1998

RHEINHEIMER, D.S.; SANTOS, E.J.S.; KAMINSKI, J.; BORTOLUZZI, E.C. \& GATIBONI, L.C. Alterações de atributos do solo pela calagem superficial e incorporada a partir de pastagem natural. R. Bras. Ci. Solo, 24:797-805, 2000

RHEINHEIMER, D.S.; PETRY, C.; KAMINSKI, J. \& BARTZ, H.R. Influência do estresse de alumínio em plantas de fumo: I. Efeito no sistema radicular, na absorção de fósforo e cálcio e na produtividade de matéria seca. R. Bras. Ci. Solo, 8:63-68, 1994.

ROSSATO, O.B. Correção da acidez em subsuperfície em um Latossolo de textura franco-arenosa sob plantio direto. Santa Maria, Universidade Federal de Santa Maria, 2008. 90p. (Tese de Mestrado).

SÁ, J.C.M. Manejo da fertilidade do solo no sistema plantio direto. In: SIQUEIRA, J.O., ed. Inter-relação fertilidade, biologia do solo e nutrição de plantas. Viçosa, SBCS; Lavras, UFLA/DCS, 1999. p.267-319. 
SALET, R.L.; ANGHINONI, I. \& KOCHHANN, R.A. Atividade de alumínio na solução de um solo no sistema plantio direto. R. Ci. Unicruz, 1:9-13, 1999.

SIDIRAS, N. \& PAVAN, M.A. Influência do sistema de manejo do solo no seu nível de fertilidade. R. Bras. Ci. Solo, 9:249$254,1985$.

SHOEMAKER, H.E.; McLEAN, E.O. \& PRATT, P.F. Buffer methods for determining lime requirement of soils with appreciable amounts of extractable aluminum. Soil Sci. Soc. Am. Proc., 25:274-277, 1961.
TEDESCO, M.J.; GIANELLO, C.; BISSANI, C.A.; BOHNEN, H. \& VOLKWEISS, S.J. Análise de solo, plantas e outros materiais. 2.ed. Porto Alegre, Universidade Federal do Rio Grande do Sul, 1995. 174p. (Boletim Técnico, 5).

USDA - SOIL SURVEY STAFF. Soil taxononmy - a basic system of soil classification for making and interpreting soil survey. 2 ed. Washington, 1999. 871p.

WEIRICH NETO, P.H.; CAIRES, E.F.; JUSTINO, A. \& DIAS, J. Correção da acidez do solo em função de modos de incorporação de calcário. Ci. Rural, 30:257-261, 2000. 
